\title{
Defining Ship Principal Dimensions Using Comparison Method
}

\author{
Renanda Bayu Harsi ${ }^{1}$, Nuzulul Arif ${ }^{1}$ \\ ${ }^{1}$ Department Naval Architecture, Adhi Tama Institute of Technology, Surabaya \\ Email: *renanda.harsi27@gmail.com, nuzulularif81@gmail.com
}

Received: 2021-09-14; Received in revised from 2021-09-22; Accepted: 2021-10-26

\begin{abstract}
Abstrak
Dalam proses mencari ukuran utama kapal terdapat berbagai metode yang dapat digunakan. Dalam studi kali ini akan digunakan Metode Perbandingan (Comparison method)) untuk mendapatkan ukuran utama kapal dan didapatkan ukuran utama kapal yakni, panjang $(L)=20.152$ meter, lebar $(B)=5.5$ meter, tinggi $(H)=2.939$ meter, sarat $(T)=1.5129$ meter, kecepatan servis $(V s)=20$ knots. Tahanan kapal sebesar $152.6 \mathrm{kN}$ pada kecepatan servis $(V s)=20$ knots dan dapat diatasi dengan daya sebesar 2426.31 HP. Daya yang diambil untuk memenuhi kebutuhan tersebut adalah sebesar 2600 HP yang disuplai oleh 2 mesin tempel (outboard engine) dengan daya masingmasing $1300 \mathrm{HP}$.
\end{abstract}

Kata Kunci: Metode Pembanding, Ukuran utama, Software Maxsurf

\begin{abstract}
In the process of finding the principal dimension of the ship there are various methods that can be used. In this study, the Comparison method will be used to obtain the main size of the ship and the main dimensions of the ship are obtained, namely, length $(\mathrm{L})=20,152$ meters, beam $(\mathrm{B})=5.5$ meters, depth $(\mathrm{H})=2,939$ meters, draft $(\mathrm{T})=1.5129$ meters, service speed $(\mathrm{Vs})=20$ knots. The ship's resistance is $152.6 \mathrm{kN}$ at service speed $(\mathrm{Vs})=20$ knots and it can be overcome with a power of $2426.31 \mathrm{HP}$. The power taken to meet these needs is $2500 \mathrm{HP}$ supplied by 2 outboard engines with a power of $1300 \mathrm{HP}$ each.
\end{abstract}

Keywords: Comparison Method, Principal Dimension, Maxsurf Software

\section{Introduction}

The ship design process is an analysis process that is repeated to obtain optimal results. Therefore, to get optimal design results and as expected, it cannot be done in one trial (one time). In designing a ship several methods can be used, including the following: (1) Comparison Method, (2) Statistical Method, (3) Trial and error/Literation method, and (4) A complex solution method.

In this study, the comparison method is used to obtain the principal dimension of the ship with the help of regression analysis. This method is simple to use and does not take a long time. After that, the calculation and drawing of the line plan, the calculation of the ship's stability and resistance are carried out. Maxsurf software is used to perform these calculations

Previous research from the proceedings [1] carried out the Geosim Procedure method to determine the main size of tourism ships in the Raja Ampat Region. In addition to the principal dimension, the calculation of the line plan, stability and ship resistance is carried out by numerical studies. [2] to design a tourist boat in the tourist area of Bali from a technical and economic point of view. The ship designed is a speed boat with a speed of 19 knots. Statistical methods are used to determine the principal dimension of the ship. The use of maxsurf software to calculate ship resistance, stability and seakeeping is carried out for fast ships with variations in deadrise [3][4]. Comparing the results of the calculation of ship resistance using Maxsurf Resistance with manual calculations has been carried out with a comparison result of $0.1 \%$ [5]. Based on that research, the principal dimension of the 
ship was calculated using the comparison method and to calculate the line plan, ship resistance and stability using Maxsurf Software.

Lines Plan is a sectional and cross-sectional image of the ship projected onto the diametral plane, the waterline plane, and the center plane of the ship. The line plan drawing becomes the main guide or the basis for the planner to carry out a complete ship design, starting from calculating the ship's characteristics, determining the division of space on the ship, determining the loading capacity of the ship, the main motor power needed to be able to move the ship according to the desired speed, as well as calculating and checking the ship's maneuverability in its voyage.

The ship's resistance at a given speed is the fluid force acting on the ship in such a way that it opposes the motion of the ship. The resistance is equal to the component of the fluid force acting parallel to the axis of motion of the ship.

The total resistance, given the notation RT, can be broken down into several different force components that are caused by a variety of causes and interact with each other in very complex ways.

\section{Method}

\subsection{Principal Dimensions}

In the process of finding the main size of the ship according to the plan, one of the methods that can be used is to use the main size data from the comparison ship, which will then be carried out linear regression analysis to find the main size of the ship. The process of compiling and determining the main size of the ship is done by making a graph with the axis $(\mathrm{X})$ as the number of passengers and the axis $(\mathrm{Y})$ as the main size of the ship.

The author takes samples of fast passenger ships as many as 10 comparison ships that can represent these statistical data, namely L (Length), B (Beam), H (Depth), T (Draft), Vs (Service Speed), is a function of the number of passengers. By using linear regression, the main size of the ship can be found from the planned number of passengers.

Table 1. Comparison Vessel Data

\begin{tabular}{|c|c|c|c|c|c|c|c|c|}
\hline No & Ship Name & $\mathbf{L}$ & B & $\mathbf{H}$ & $T$ & Vs & BHP & $\begin{array}{l}\text { Number of } \\
\text { Passengers }\end{array}$ \\
\hline 1 & Jawa Boat & 17.25 & 5.36 & 2.05 & 0.9 & 28 & 1360 & 50 \\
\hline 2 & $\begin{array}{l}\text { Natuna } \\
\text { Ekspres }\end{array}$ & 12.07 & 5.46 & 1.75 & 0.5 & 25 & 920 & 25 \\
\hline 3 & Gili Iyang & 11.97 & 5.41 & 1.86 & 1.1 & 14 & 300 & 65 \\
\hline 4 & Trisna & 15.79 & 6.36 & 2.03 & 1.2 & 17 & 600 & 73 \\
\hline 5 & Arjuna & 14.3 & 6 & 2.25 & 1.33 & 25 & 860 & 95 \\
\hline 6 & $\begin{array}{l}\text { Gerbang } \\
\text { Samudra }\end{array}$ & 12.8 & 6.2 & 2.73 & 1.4 & 22 & 620 & 98 \\
\hline 7 & $\begin{array}{l}\text { Putri Sri } \\
\text { Tanjung }\end{array}$ & 16.6 & 6.5 & 2.28 & 1.35 & 22 & 620 & 80 \\
\hline 8 & $\begin{array}{l}\text { Rajawali } \\
\text { Nusantara }\end{array}$ & 13.85 & 5.3 & 1.77 & 1.05 & 20 & 400 & 74 \\
\hline 9 & $\begin{array}{l}\text { Satria } \\
\text { Nusantara }\end{array}$ & 9 & 3.7 & 0.67 & 0.4 & 25.5 & 200 & 13 \\
\hline 10 & Bahari & 14.5 & 5.36 & 1.75 & 1.25 & 28 & 1160 & 55 \\
\hline
\end{tabular}

After obtaining the principal dimensions, we can calculate the ship's loading capacity using the formula (1).

$$
D W T=P_{B}\left(1+R \times V_{S}^{3} / 10^{6}\right)
$$




\subsection{Lines Plan}

In this study, the ship model was created using the Maxsurf software. The principal dimension of the ship is obtained from 10 comparison ship data and a regression analysis is carried out between the principal dimension of the ship and the number of passengers. The selected hull shape is based on the existing hull shape in the sample design provided by the program. The ship's principal dimension that has been determined is inputted into the Surface menu, Surface Size. Figure 1 shows the main ship size input process

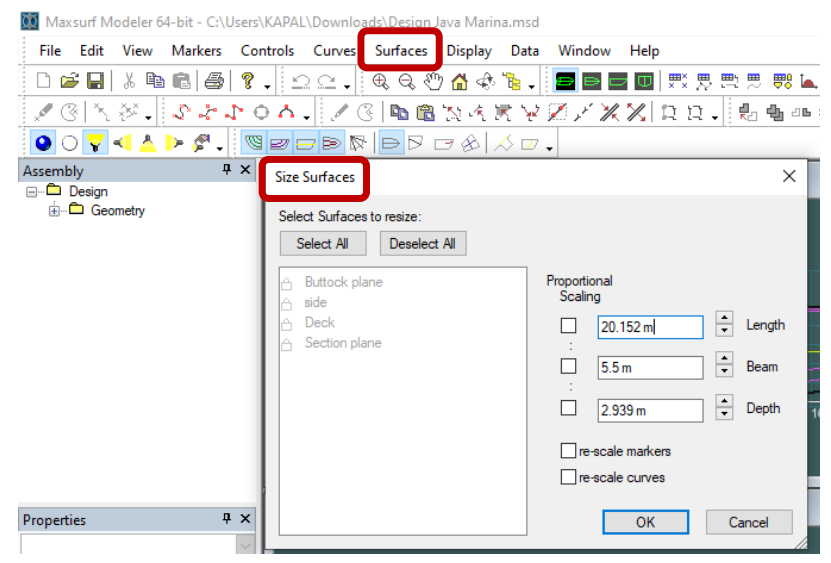

Figure 1. Input the principal dimension of the ship on the surface menu

\subsection{Resistance}

In this study, the calculation of ship resistance is assisted by using the Maxsurf software. The Wyman calculation method is used to calculate the ship's resistance. This choice was made because this method is suitable for speed boats with a planning hull model. In addition, the hull used is of a normal shape so that it fits the Wyman method [6].

\subsection{Stability}

Ship stability is calculated using maxsurf software and calculated for several conditions (load case), namely: (1) Empty State, (2) Load 100\% Consumable 90\%, and (3) Load 0\% Consumable $90 \%$. Stability criteria used are IMO criteria for all types of ships [7].

Table 2. Empty State

\begin{tabular}{llllllllll}
\hline No & Item Name & Quantity & $\begin{array}{l}\text { Unit } \\
\text { Mass } \\
{[\text { tone] }}\end{array}$ & $\begin{array}{l}\text { Total } \\
\text { Mass } \\
{[\text { tone] }}\end{array}$ & $\begin{array}{l}\text { Unit } \\
\text { Volume } \\
{\left[\mathbf{m}^{3}\right]}\end{array}$ & $\begin{array}{l}\text { Total } \\
\text { Volume } \\
{\left[\mathbf{m}^{3}\right]}\end{array}$ & $\begin{array}{l}\text { Long. } \\
\text { Arm } \\
{[\mathbf{m}]}\end{array}$ & $\begin{array}{l}\text { Trans. } \\
\text { Arm } \\
{[\mathbf{m}]}\end{array}$ & $\begin{array}{l}\text { Vert. } \\
\text { Arm }\end{array}$ \\
\hline 1 & Lightship & 1 & 81.242 & 81.242 & & & 8.753 & 0 & 1.774 \\
2 & Passenger & 0 & 0 & 0 & & & 8.753 & 0 & 1.774 \\
3 & Fuel & $0 \%$ & 8 & 0 & 8.471 & 0 & 13.3 & 0 & 1 \\
4 & Total Load & & & 81.242 & 8.471 & 0 & 8.753 & 0 & 1.774 \\
& case & & & & & & & 0 \\
5 & FS & & & & & & & \\
& correction & & & & & & & & \\
6
\end{tabular}

Table 3. Load 100\% Consumable 90\%

\begin{tabular}{llllllllll}
\hline No & Item Name & Quantity & $\begin{array}{l}\text { Unit } \\
\text { Mass } \\
{[\text { tone] }}\end{array}$ & $\begin{array}{l}\text { Total } \\
\text { Mass } \\
{[\text { tone] }}\end{array}$ & $\begin{array}{l}\text { Unit } \\
\text { Volume } \\
{\left[\mathbf{m}^{3}\right]}\end{array}$ & $\begin{array}{l}\text { Total } \\
\text { Volume } \\
{\left[\mathbf{m}^{3}\right]}\end{array}$ & $\begin{array}{l}\text { Long. } \\
\text { Arm } \\
{[\mathbf{m}]}\end{array}$ & $\begin{array}{l}\text { Trans. } \\
\text { Arm } \\
{[\mathbf{m}]}\end{array}$ & $\begin{array}{l}\text { Vert. } \\
\text { Arm }\end{array}$ \\
\hline 1 & Lightship & 1 & 81.242 & 81.242 & & & 8.753 & 0 & 1.774 \\
2 & Passenger & 100 & 0.07 & 7 & & & 8.753 & 0 & 1.774
\end{tabular}




\begin{tabular}{|c|c|c|c|c|c|c|c|c|c|}
\hline No & Item Name & Quantity & $\begin{array}{l}\text { Unit } \\
\text { Mass } \\
\text { [tone] } \\
\end{array}$ & $\begin{array}{l}\text { Total } \\
\text { Mass } \\
\text { [tone] } \\
\end{array}$ & $\begin{array}{l}\text { Unit } \\
\text { Volume } \\
{\left[\mathrm{m}^{3}\right]}\end{array}$ & $\begin{array}{l}\text { Total } \\
\text { Volume } \\
{\left[\mathrm{m}^{3}\right]} \\
\end{array}$ & $\begin{array}{l}\text { Long. } \\
\text { Arm } \\
{[\mathrm{m}]} \\
\end{array}$ & $\begin{array}{l}\text { Trans. } \\
\text { Arm } \\
{[\mathrm{m}]}\end{array}$ & $\begin{array}{l}\text { Vert. } \\
\text { Arm }\end{array}$ \\
\hline 3 & Fuel & $90 \%$ & 8 & 7.2 & 8.471 & 7.624 & 13.3 & 0 & 1 \\
\hline 4 & $\begin{array}{l}\text { Total Load } \\
\text { case }\end{array}$ & & & 95.442 & 8.471 & 7.624 & 8.753 & 0 & 1.774 \\
\hline 5 & $\begin{array}{l}\text { FS } \\
\text { correction }\end{array}$ & & & & & & & & 0.041 \\
\hline 6 & VCG fluid & & & & & & & & 1.798 \\
\hline
\end{tabular}

Table 4. Load $0 \%$ Consumable $90 \%$

\begin{tabular}{llllllllll}
\hline No & Item Name & Quantity & $\begin{array}{l}\text { Unit } \\
\text { Mass } \\
{[\text { tone] }}\end{array}$ & $\begin{array}{l}\text { Total } \\
\text { Mass } \\
{[\mathbf{t o n e}]}\end{array}$ & $\begin{array}{l}\text { Unit } \\
\text { Volume } \\
{\left[\mathbf{m}^{3}\right]}\end{array}$ & $\begin{array}{l}\text { Total } \\
\text { Volume } \\
{\left[\mathbf{m}^{3}\right]}\end{array}$ & $\begin{array}{l}\text { Long. } \\
\text { Arm } \\
{[\mathbf{m}]}\end{array}$ & $\begin{array}{l}\text { Trans. } \\
\text { Arm } \\
{[\mathbf{m}]}\end{array}$ & $\begin{array}{l}\text { Vert. } \\
\text { Arm }\end{array}$ \\
\hline 1 & Lightship & 1 & 81.242 & 81.242 & & & 8.753 & 0 & 1.774 \\
2 & Passenger & 0 & 0.07 & 0 & & & 8.753 & 0 & 1.774 \\
3 & Fuel & $90 \%$ & 8 & 7.2 & 8.471 & 7.624 & 13.3 & 0 & 1.55 \\
4 & Total Load & & & 88.442 & 8.471 & 7.624 & 9.123 & 0 & 1.756 \\
& case & & & & & & & & 0.044 \\
5 & FS & & & & & & & 1.8 \\
& correction & & & & & & & & \\
6
\end{tabular}

\section{Results and Discussion}

From the graph in Figure 2, the author gets the formula for the equation of the line, namely $y=$ $0.0431 \mathrm{x}+11.134$, with $\mathrm{R}^{2}=0.2329$. The value of $\mathrm{R}^{2}$ is used to predict how much influence the independent variable (x) has in this case the number of passengers on the dependent variable (y) in this case the length of the ship. This $\mathrm{R}^{2}$ value shows a less strong relationship between the $\mathrm{x}$ and $\mathrm{y}$ variables because the value of 0.2329 is closer to 0 . The writer replaces the variable $\mathrm{x}$ with the planned number of passengers.

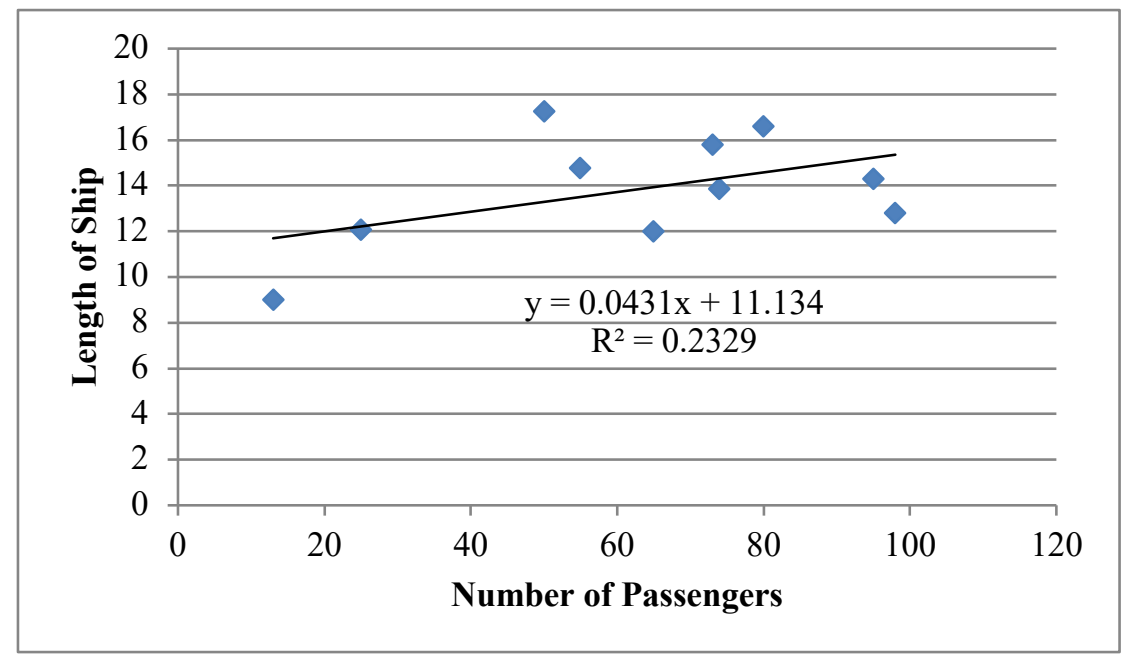

Figure 2. Graph of the relationship between the number of passengers and the length of the ship (L)

From the graph in Figure 3, the author gets the formula for the equation of the line, namely $y=$ $0.0228 \mathrm{x}+4.1324$, with $\mathrm{R}^{2}=0.6263$. This $\mathrm{R}^{2}$ value shows a strong relationship between the $\mathrm{x}$ and $\mathrm{y}$ variables because the value is closer to 1 . The writer replaces the variable $\mathrm{x}$ with the planned number of passengers. 




Figure 3. Graph of the relationship between the number of passengers and the beam of the ship (B)

From the graph in Figure 4, the author gets the formula for the equation of the line, namely $y=$ $0.0163 \mathrm{x}+0.8916$, with $\mathrm{R}^{2}=0.7158$. This $\mathrm{R}^{2}$ value shows a strong relationship between the $\mathrm{x}$ and $\mathrm{y}$ variables because the value is closer to 1 . The writer replaces the variable $\mathrm{x}$ with the planned number of passengers.

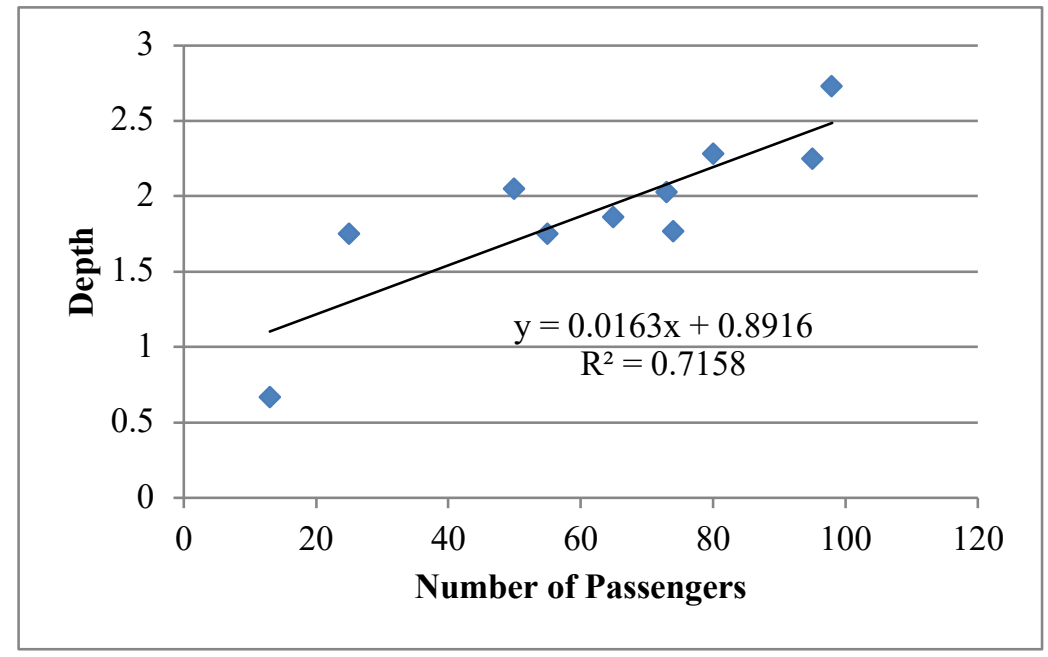

Figure 4. Graph of the relationship between the number of passengers and the depth of the ship (H)

From the graph in Figure 5, the author gets the formula for the equation of the line, namely $y=$ $0.0118 \mathrm{x}+0.3091$, with $\mathrm{R}^{2}=0.8708$. This $\mathrm{R}^{2}$ value shows a strong relationship between the $\mathrm{x}$ and $\mathrm{y}$ variables because the value is closer to 1 . The writer replaces the variable $\mathrm{x}$ with the planned number of passengers. 


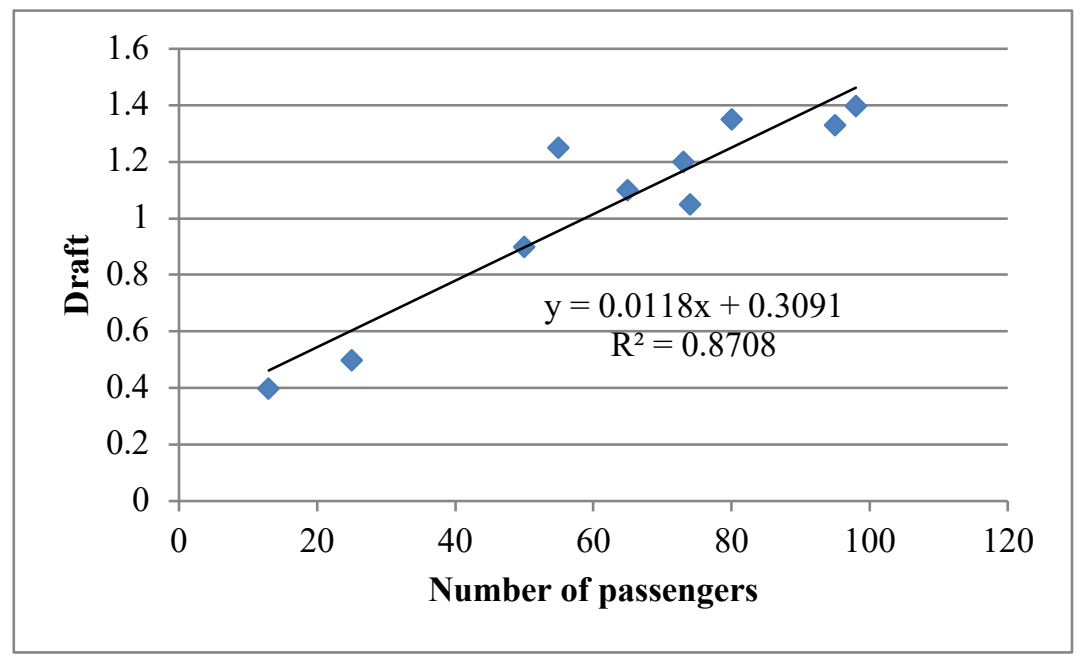

Figure 5. The graph of the relationship between the number of passengers and the ship's draft (T)

From the graph in Figure 6, the author gets the formula for the equation of the line, namely $y=$ $-0.0585 x+26,321$, with $R^{2}=0.1242$. This $R^{2}$ value shows a less strong relationship between the $x$ and $\mathrm{y}$ variables because the value of 0.1242 is closer to 0 . The writer replaces the variable $\mathrm{x}$ with the planned number of passengers.

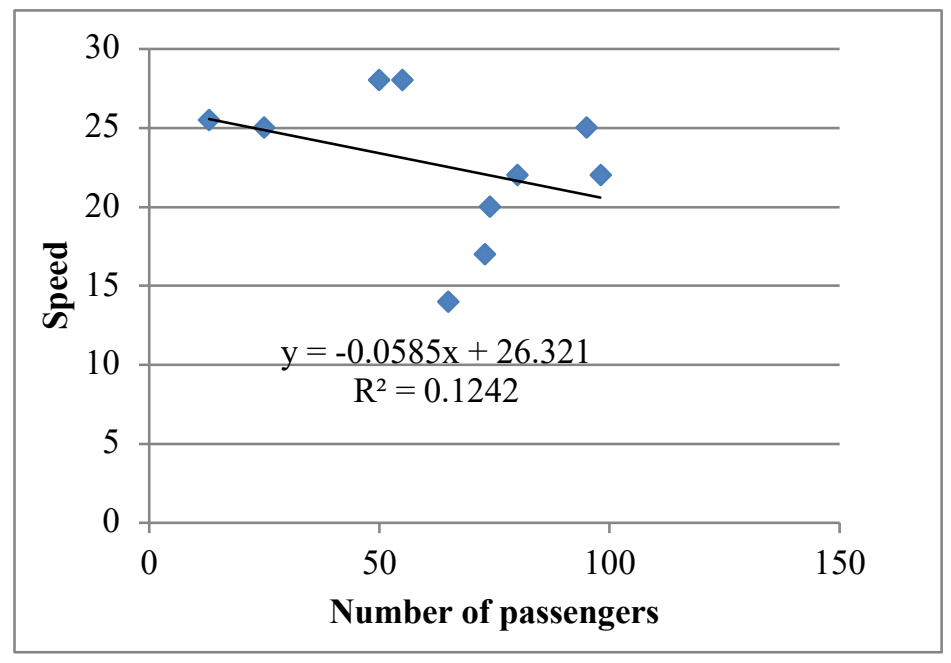

Figure 6. Graph of the relationship between the number of passengers and the service speed of the ship (Vs)

From the linear regression calculation above, it is obtained that the main size of the fast passenger ship planned in Table 5.

Tabel 5. Principal Dimensions

\begin{tabular}{llll}
\hline No & Item & Value & Units \\
\hline 1 & Ship Name & Java Marine Pratama & \\
2 & Length (L) & 20.152 & $\mathrm{M}$ \\
3 & Breadth (B) & 5.5 & $\mathrm{M}$ \\
4 & Height (H) & 2.939 & $\mathrm{M}$ \\
5 & Draft (T) & 1.513 & $\mathrm{M}$ \\
6 & Velocity of Service (Vs) & 20 & $\mathrm{Knots}$ \\
& & 10.288 & $\mathrm{~m} / \mathrm{s}$ \\
\hline
\end{tabular}




\subsection{Lines Plan}

The ship model was created using Maxsurf software. The resulting ship hull model is as followson Figure 7, Figure 8 and Figure 9.

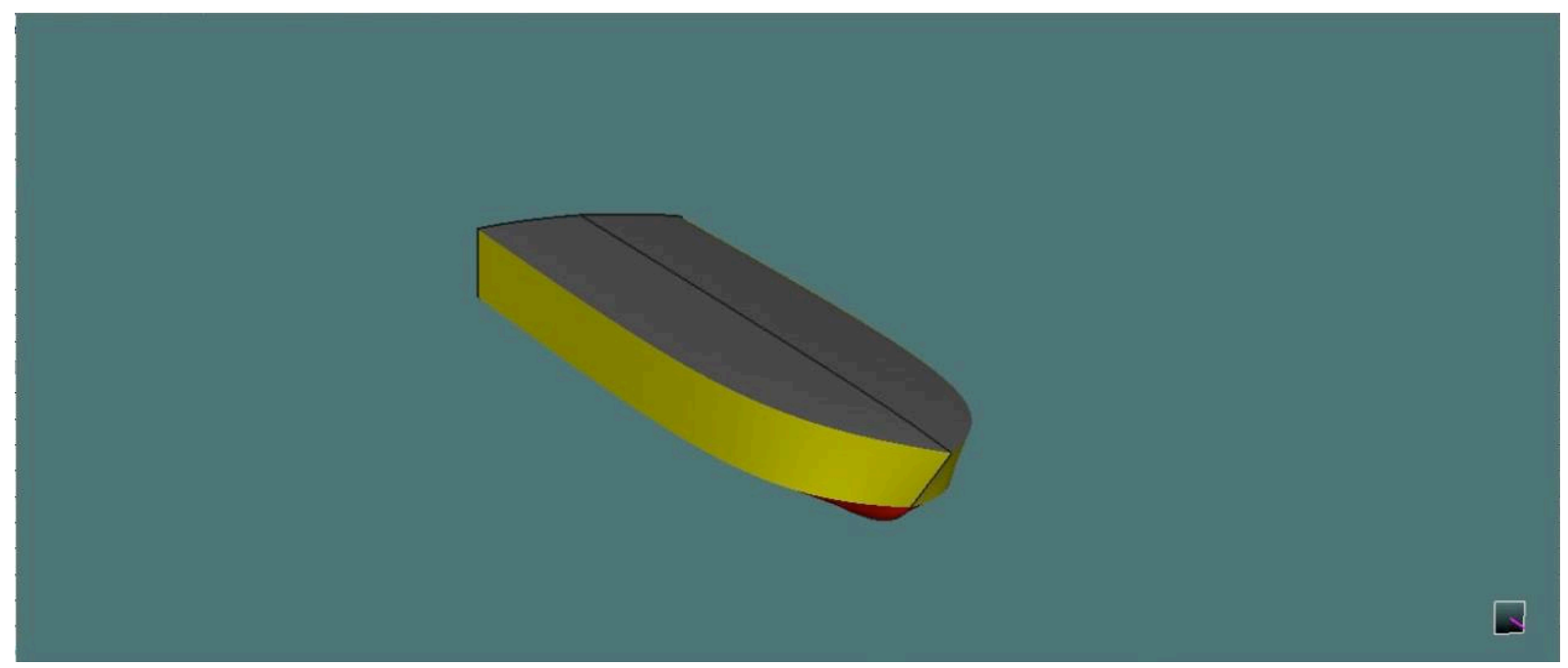

Figure 7. Perspective View of Hull Model

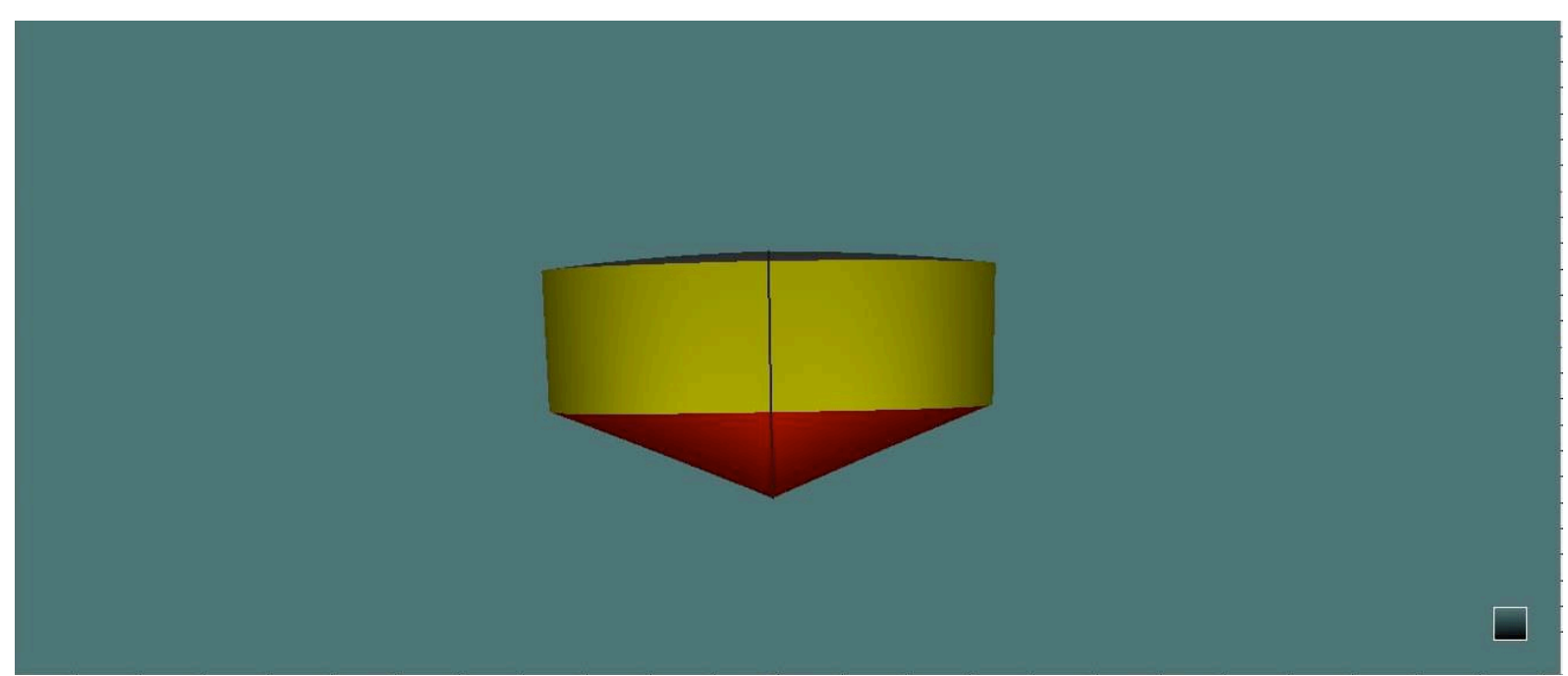

Figure 8. Body View of Hull Model 


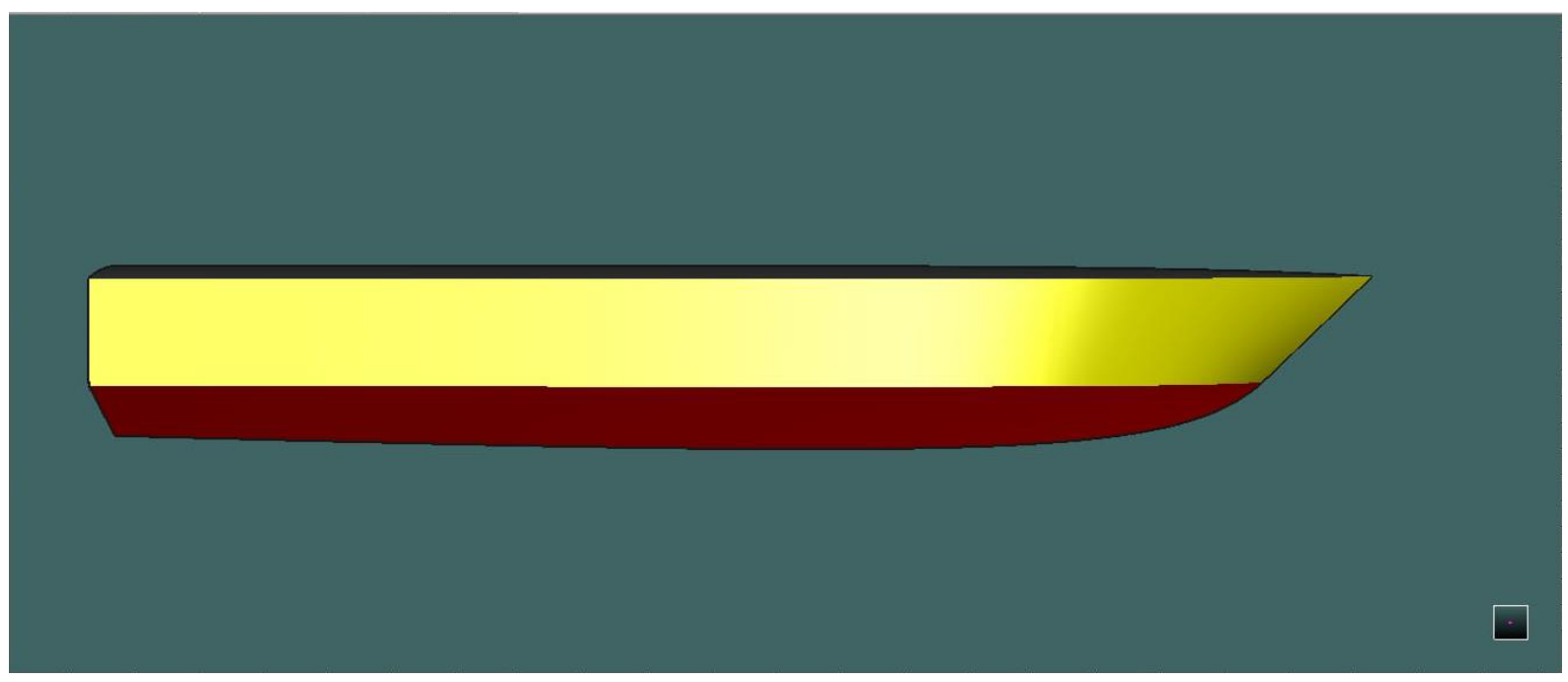

Figure 9. Profile View of Hull Model

\subsection{Stability}

The calculation results can be seen Table 6 and Figure 10 for below.

Table 6. Stability Calculation Results Criteria for Empty State

\begin{tabular}{lll}
\hline No & Criteria & Status \\
\hline 1 & Area $0^{\circ}$ to $30^{\circ}$ & Pass \\
2 & Area $0^{\circ}$ to $30^{\circ}$ & Pass \\
3 & Area $0^{\circ}$ to $30^{\circ}$ & Pass \\
4 & Max GZ at 30 or greater & Pass \\
5 & Angle of Maximum GZ & Pass \\
6 & Initial GMt & Pass \\
\hline
\end{tabular}

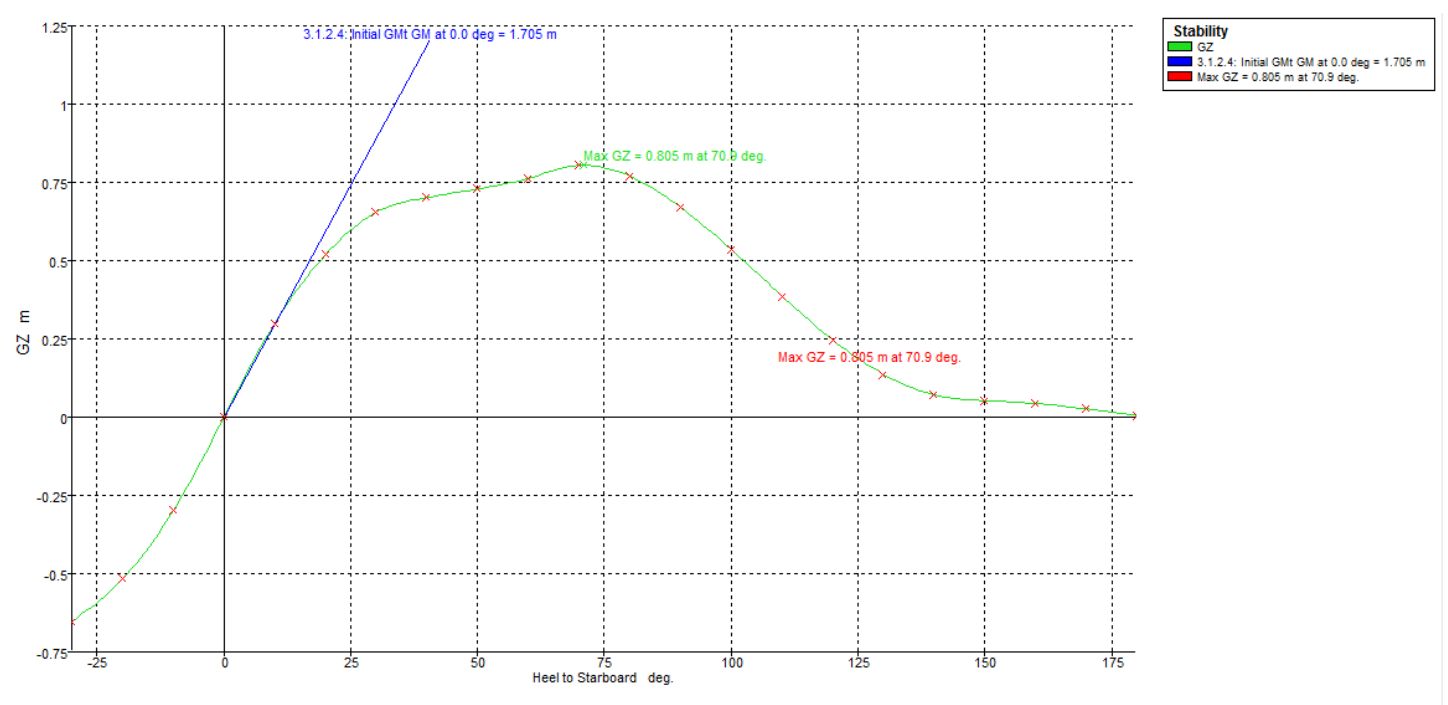

Figure 10. Graph of Stability Calculation Results for Empty State 
Table 7. Stability Calculation Results Criteria for Load 100\% Consumable 90\%

\begin{tabular}{lll}
\hline No & Criteria & Status \\
\hline 1 & Area $0^{\circ}$ to $30^{\circ}$ & Pass \\
2 & Area $0^{\circ}$ to $30^{\circ}$ & Pass \\
3 & Area $0^{\circ}$ to $30^{\circ}$ & Pass \\
4 & Max GZ at 30 or greater & Pass \\
5 & Angle of Maximum GZ & Pass \\
6 & Initial GMt & Pass \\
\hline
\end{tabular}

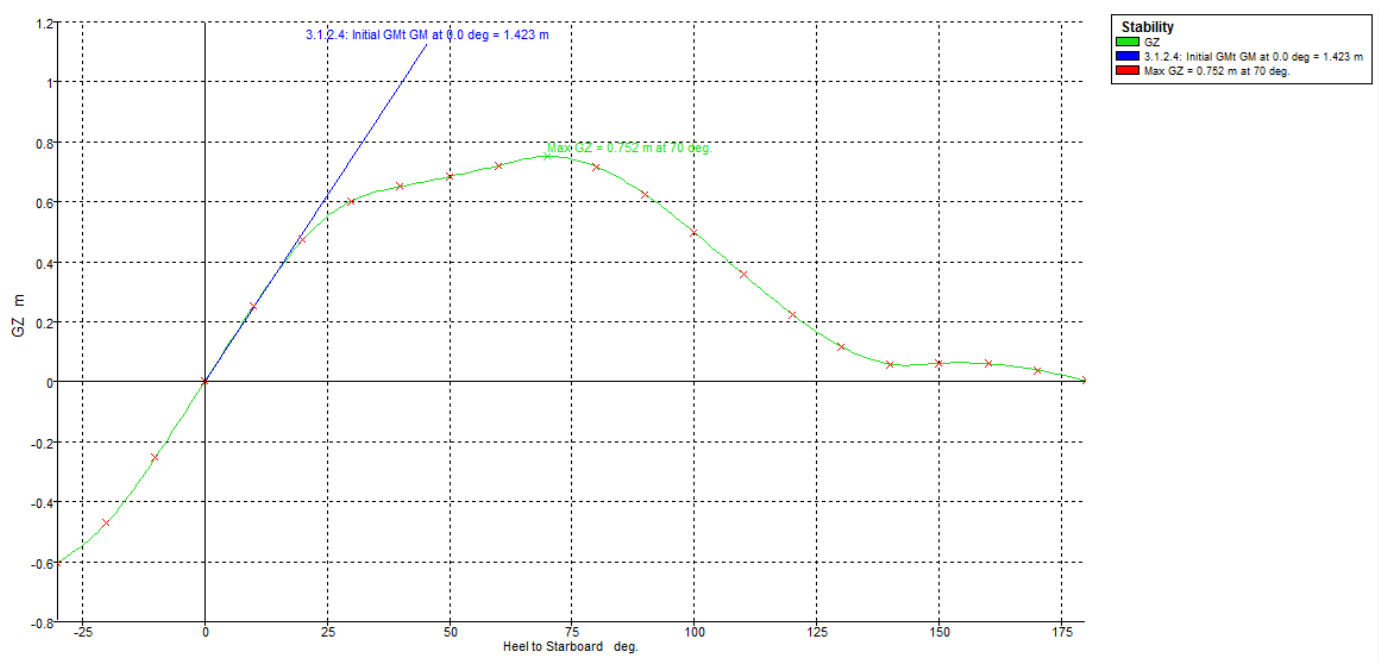

Figure 11. Graph of Stability Calculation Results for Load 100\% Consumable 90\%

Table 8. Stability Calculation Results Criteria for Load $0 \%$ Consumable $90 \%$

\begin{tabular}{lll}
\hline No & Criteria & Status \\
\hline 1 & Area $0^{\circ}$ to $30^{\circ}$ & Pass \\
2 & Area $0^{\circ}$ to $30^{\circ}$ & Pass \\
3 & Area $0^{\circ}$ to $30^{\circ}$ & Pass \\
4 & Max GZ at 30 or greater & Pass \\
5 & Angle of Maximum GZ & Pass \\
6 & Initial GMt & Pass \\
\hline
\end{tabular}


Figure 12. Graph of Stability Calculation Results for Load 0\% Consumable 90\% 
Based on the calculation of stability with the three shipping conditions above, it is concluded that all stability criteria have been met according to IMO. So it can be concluded that the selection of this basic size is correct in terms of ship stability.

\subsection{Resistance}

The calculation of resistance and engine power is obtained from ship model simulation using the maxsurf model with a test speed of 20 knots, the method used is Wyman and the efficiency is $90 \%$ [8]. Table 9 is simulation results.

Table 9. The results of the calculation of Resistance with Maxsurf

\begin{tabular}{lllll}
\hline No & Speed [knots] & Froude No. LWL & $\begin{array}{l}\text { Wyman Resist. } \\
{[\mathrm{kN}]}\end{array}$ & $\begin{array}{l}\text { Wyman Power } \\
{[\mathrm{HP}]}\end{array}$ \\
\hline 1 & 0 & 0 & 0 & 0 \\
2 & 1 & 0.038 & 0.5 & 0.407 \\
3 & 2 & 0.076 & 2.1 & 3.256 \\
4 & 3 & 0.113 & 4.8 & 10.988 \\
5 & 4 & 0.151 & 8.5 & 26.045 \\
6 & 5 & 0.189 & 13.3 & 50.868 \\
7 & 6 & 0.227 & 19.1 & 87.9 \\
8 & 7 & 0.265 & 26 & 139.582 \\
9 & 8 & 0.303 & 34 & 208.356 \\
10 & 9 & 0.34 & 43 & 296.663 \\
11 & 10 & 0.378 & 53.1 & 406.946 \\
12 & 11 & 0.416 & 64.2 & 541.645 \\
13 & 12 & 0.454 & 76.4 & 893.202 \\
14 & 13 & 0.492 & 89.7 & 1116.659 \\
15 & 14 & 0.529 & 104.1 & 1373.441 \\
16 & 15 & 0.567 & 119.5 & 1635.405 \\
17 & 16 & 0.605 & 133.3 & 1826.915 \\
18 & 17 & 0.643 & 140.2 & 2023.07 \\
19 & 18 & 0.681 & 146.6 & 2223.101 \\
20 & 19 & 0.719 & 152.6 & 2426.31 \\
21 & 20 & 0.756 & 158.3 & \\
\hline
\end{tabular}

Based on the simulation results at Maxsurf, with a service speed of 20 knots, the required power is $2426.31 \mathrm{HP}$. The power taken to meet these needs is $2600 \mathrm{HP}$ supplied by 2 outboard engines with a power of $1300 \mathrm{HP}$ each and a weight of $970 \mathrm{Kg}$ each $(2 \times 970=1940 \mathrm{Kg})$.

\section{Conclusion}

The main dimensions of the ship are obtained, namely, length $(\mathrm{L})=20,152$ meters, width $(\mathrm{B})=$ 5.5 meters, height $(\mathrm{H})=2,939$ meters, $\operatorname{draft}(\mathrm{T})=1,5129$ meters, service speed $(\mathrm{Vs})=20$ knots. The ship's resistance is $152.6 \mathrm{kN}$ at service speed $(\mathrm{Vs})=20$ knots. It can be overcome with a power of $2426.31 \mathrm{HP}$. The power taken to meet these needs is $2600 \mathrm{HP}$ supplied by 2 outboard engines with a power of $1300 \mathrm{HP}$ each.

\section{References}

[1] E. Pranatal and B. Ramadhan, "Studi Perancangan Kapal Wisata Daerah Raja Ampat," Pros. Semin. Teknol. Kebumian dan Kelaut., vol. 3, no. 1, pp. 36-42, Aug. 2021, doi: 10.31284/P.SEMITAN.2021.1984.

[2] K. A. Indrawan, P. I. Santosa, and S. Soejitno, "Perancangan Kapal Penumpang Cepat di Pantai Sanur", Skripsi Bachelor, Fakultas Teknologi Mineral dan Keluatan, ITATS, 2019 
[3] E. Pranatal, "Pengaruh Sudut Deadrise Terhadap Tahanan Planning Hull," Pros. Semin. Teknol. Kebumian dan Kelaut., vol. 2, no. 1, pp. 649-655, Jul. 2020, doi: 10.31284/P.SEMITAN.2020.1050.

[4] E. Pranatal, "Analisis Pengaruh Sudut Deadrise Planning Craft Terhadap Stabilitas Dan Seakeeping," Wave J. Ilm. Teknol. Marit., vol. 14, no. 2, pp. 61-72, Feb. 2020, doi: 10.29122/JURNALWAVE.V14I2.4454.

[5] R. Rachman, E. Pranatal, and P. I. S, “Analisis Perbandingan Metode Simulasi Software Maxsurf Dengan Metode Matematis Untuk Perhitungan Hambatan Dan Daya Mesin Utama Kapal Tanker 6500 Dwt," Pros. Semin. Teknol. Kebumian dan Kelaut., vol. 2, no. 1, pp. 193-201, Jul. 2020, doi: 10.31284/P.SEMITAN.2020.1079.

[6] B. Suwasono, A. Munazid, R. Awwalin, G. A. P. Poundra, and Sutiyo, "Teori Dan Panduan Praktis Hidrodinamika Kapal Hukum Archimedes," Sep. 2019, Accessed: Oct. 11, 2021. [Online]. Available: http://dspace.hangtuah.ac.id:8080/xmlui/handle/dx/920.

[7] P. I. Santosa, I. K. A. P. Utama, and T. W. W. Pribadi, "Stability Analysis of Hybrid Catamaran Fishing Vessel," no. October, 2014.

[8] Dian, P., et al. "Application of Kalman Filter to the uncertainty of Model Resistance Data obtained from experiment." Journal of Engineering Science and Technology 15.2 (2020): 14551465 . 